Printed by: serliw@ petra.ac.id. Printing is for personal, private use only. No part of this book may be reproduced or transmitted without publisher's prior permission. Violators will be prosecuted.

\title{
The influence of destination image on tourist satisfaction and tourist loyalty: A case study of urban tourism in Semarang, Indonesia
}

\author{
G.P.M. Agung, S. Wijaya \& D.C. Widjaja \\ Faculty of Business and Economics Petra Christian University, Surabaya, Indonesia
}

\begin{abstract}
Urban tourism has gained its popularity as an alternative in cities offering various tourism experiences not only for visitors but also for city residents. Semarang has evolved as one of the major urban tourism destinations in Indonesia, showing increasing visitor arrival every year. The city has a wide range of potential tourist attractions including heritage tourism, religious tourism, shopping tourism at traditional markets, and culinary tourism. Despite its prospective growth and extensive efforts of the local government to promote the destination, the number of tourists who visit Semarang is still behind its neighbouring cities like Yogyakarta and Solo. This study aimed to identify the image of Semarang as a tourism destination and to examine whether both cognitive and affective images of the city affected tourist satisfaction and tourist loyalty. The survey was completed by 300 respondents who were domestic tourists not residing in Semarang and had visited the city at least within the past year. The results showed that destination image significantly and positively influenced tourist satisfaction and induced the intention of tourists to revisit Semarang, with cognitive image having a stronger effect than affective image.
\end{abstract}

\section{INTRODUCTION}

In the past few decades, urban tourism has been growing dramatically in big cities in many countries, and it is seen as the socioeconomid phenomena in the modern era. Urban tourism is related to the increase of tourism activities in the urban areas that significantly support the local economy (Selby, 2004). It ranges from shopping, culinary, sport, business activities, and culture-related events like art and music performance and exhibitions. The growth of urban tourism is linear with the increased urban population due to migration to the cities (Griffin \& Dimanche, 2017). Urban tourism has been strategically promoted for tourism by neighbouring countries such as Singapore and Thailand. Indonesia, as an archipelagic country, has plenty of tourist destinations including cities with a close relationship with history and heritage. Semarang is one of the old cities in Indonesia with has many historical buildings that can attract tourists. Semarang is the capital city of Central Java province as well as the fifth-largest metropolitan city in Indonesia after Jakarta, Surabaya, Medan, and Bandung. Statistics Indonesia recorded that since 2014, the number of tourist arrivals in Semarang has increased significantly to reach more than 4 million people.

Literature has indicated the importance of destination image as a determinant of tourists visiting to a city, which in turn, would lead to tourist satisfaction and loyalty. On this basis, this current empirical research was applied to investigate the image of Semarang as a tourism destination. A preliminary survey studied 300 domestic tourists in Semarang to explore the image of the city as an urban destination, as well as to determine tourists' impressions during a visit in Semarang. The result of the preliminary survey revealed that Semarang was perceived as a transit city only. According to Hanifa 
Printed by: serliw@petra.ac.id. Printing is for personal, private use only. No part of this book may be reproduced or transmitted without publisher's prior permission. Violators will be prosecuted.

(2012), changes are required to promote Semarang as a holiday destination. In fact, Semarang could become the leading tourism destination of Central Java province. This could be accomplished via a strategic plan to build the image of Semarang as a tourism destination in the minds of tourists who visit the city. In the long term, the image analysis of tourist destinations in Semarang would become one of the significant inputs for various tourism stakeholders, especially the government of Semarang.

Resources and infrastructure have impacts on the image of a destination. The image of a destination is not just a photograph. It is an impression, perception, understanding, belief, and emotional thinking (Yeh, 2012). According to Beerli and Martin (2004), two factors affect the image of the destination: information sources and personal factors. Information sources are the most critical factors in influencing perception formation and evaluation. Tourists refer to the amount and variety of information obtained about a destination. Information sources are components in the cognitive image. The second factor is the tourists' psychological and emotional impression of a place or destination, so it is important that people do not just visit but also have a positive impression. Personal factor is a component in the affective image. A higher level of satisfaction will have an impact on the level of tourist loyalty (Coban, 2012). When tourists are satisfied, they return, so loyalty is achieved. Loyalty must be maintained so that tourists provide recommendations to colleagues; loyalty can inform an image of a destination (Artuger et al., 2013).

\section{LITERATURE}

Destination image is one crucial factor that can influence tourists in choosing a destination. The definition of the destination image focuses on a person's perception of a region (Chiu, 2016). The image of a destination will also have a positive impact that affects tourist satisfaction and loyalty (Coban, 2012). According to Kotler and Keller (2009), the image of a destination is a number of beliefs, ideas, and impressions held by a person about an object. The image of a destination is not just a photograph; it is an impression, perception, understanding, belief, and emotional thinking (Yeh, 2012). The positive image of a destination will indirectly affect tourist satisfaction, and it is the basis for tourists to make a return visit. If each destination provides adequate accommodation and accessibility for travellers, it will also provide job opportunities and improve the economy of the area (Coban, 2012).

Kotler and Keller (2009) state that the concept of satisfaction is generally defined as the feeling of satisfied or disheartened consumers that results from comparing the perceived performance of a product (or outcome) with consumer expectations. In the context of tourism, customer satisfaction is called tourist satisfaction. It can be regarded as a post-visit evaluation of a destination. Tourist satisfaction is an overall measure of tourist opinions of destination quality. Tourism satisfaction plays a vital role as a marketing tool to attract consumers and also make plans about what products and services are provided in the tourism market. The level of traveller satisfaction is evaluated by the difference between past tourist experience and current conditions, as well as the comparison between current travel objectives with alternative destinations or other places visited in the past (Wang, 2017).

Oliver (1999) states that loyalty is a firm commitment to repurchase or subscribe in the future to products/services that are consistently favored, resulting in the purchase of the same brand, regardless of experiments and marketing efforts that have the potential to cause switching behaviour. Consumer loyalty in the field of tourism is the loyalty of tourists who visit the area. Tourist loyalty is an essential aspect for marketers of a destination, as it is more attractive and less expensive to retain existing tourists than to find new travellers (Chiu, 2016). Travellers with a high level of loyalty are an essential asset for the market segment of a destination. This is because, in general, return tourists will stay longer than first-time visitors and will tend to spread positive information by word of mouth (WOM) to family and colleagues. This will 
Printed by: serliw@petra.ac.id. Printing is for personal, private use only. No part of this book may be reproduced or transmitted without publisher's prior permission. Violators will be prosecuted.

be beneficial for marketers as it can reduce marketing costs compared to attracting visitors for the first time (Chiu, 2016).

Based on the review of the literature, six hypotheses are being formulated as follows:

H1: Cognitive image has a positive and significant effect on affective image.

$\mathrm{H} 2$ : Cognitive image has a positive and significant effect on tourist satisfaction.

H3: Cognitive image has a positive and significant effect on tourist loyalty.

H4: Affective image has a positive and significant effect on tourist satisfaction.

H5: Affective image has a positive and significant effect on tourist loyalty.

H6: Tourist satisfaction has a positive and significant effect on tourist loyalty.

\section{METHODOLOGY}

A closed-ended questionnaire survey was completed utilising both online and offline to reach a minimum of 300 samples. The survey was completed by 300 respondents, but only 291 questionnaires were valid and could be analysed further.

\section{RESULT}

\subsection{Respondents profiles}

There is a balanced percentage in terms of the participants. Half the participants were between 23 and 28 years old. In terms of the travel characteristics, the majority of participants often travel to Semarang for business purpose $(52.7 \%)$, spending about three days in the city each time. This confirms the preliminary survey result that the image of Semarang was as a transit city.

There are four variables: cognitive image, affective image, tourist satisfaction, and tourist loyalty. Cognitive image has 17 indicators, but only 14 were valid, affective image has two indicators, tourist satisfaction has three indicators, and tourist loyalty has four indicators. All indicators of affective image variable, tourist satisfaction, and tourist loyalty had outer loading scores above 0.5 except cognitive image indicators. The indicators that had the lowest score are: CI-14 (diverse cuisine) score 0.542; CI-13 (accessibility) score 0.558; CI-17 (friendliness of local residents) score 0.601 ; and CI-9 (city cleanliness for public spaces) score 0.637 .

\subsection{Hypothesis test}

Research hypothesis can be accepted if the value of $t$-statistics $>t$-table at the error rate $(\alpha)$ $5 \%$ is 1.96 . Table 1 illustrates the coefficient values (original sample estimate) and the $t$-statistics generated on the inner model.

Table 1 shows that out of six hypotheses, five of them were acceptable, while only H5 was rejected. The results showed that cognitive image variables affect affective image. Cognitive image is the result of the eyaluation of tourists who live in and visit the city of Semarang. The results of these evaluations will affect each tourist's emotional

Table 1. Coefficient path result.

\begin{tabular}{llllrl}
\hline & $\begin{array}{l}\text { Original Sample } \\
\text { Estimate }\end{array}$ & $\begin{array}{l}\text { Mean of } \\
\text { Subsamples }\end{array}$ & $\begin{array}{l}\text { Standard } \\
\text { Deviation }\end{array}$ & $t$-Statistic & Result \\
\hline Cognitive -> Affective & 0.716 & 0.721 & 0.036 & 20.030 & Accepted \\
Cognitive - > Satisfaction & 0.346 & 0.351 & 0.090 & 3.851 & Accepted \\
Cognitive - Loyalty & 0.227 & 0.229 & 0.083 & 2.730 & Accepted \\
Affective -> Satisfaction & 0.490 & 0.488 & 0.087 & 5.605 & Accepted \\
Affective -> Loyalty & 0.094 & 0.093 & 0.058 & 1.604 & Rejected \\
Satisfaction - > Loyalty & 0.538 & 0.537 & 0.079 & 6.793 & Accepted \\
\hline
\end{tabular}


Printed by: serliw@petra.ac.id. Printing is for personal, private use only. No part of this book may be reproduced or transmitted without publisher's prior permission. Violators will be prosecuted.

impression (affective image). The emotional impression that tourists have will have an impact on satisfaction. If the perceived experience exceeds expectations, then the tourists are satisfied.

Conversely, if the perceived experience does not exceed expectations, then tourists are not satisfied. Such perceived satisfaction tends to affect the level of loyalty. Based on the research results, it can be seen that there are five accepted hypotheses, and one hypothesis rejected. The hypothesis rejected is the relationship between affective image with loyalty tourists. Affective image proved not to affect the loyalty of tourists. This finding is consistent with Coban (2012) and Prayag (2011) that travellers should be satisfied in advance and then reach the point of loyalty.

\section{CONCLUSION AND SUGGESTIONS}

The findings of the current article confirm that cognitive image has a positive and significant impact on affective image. Cognitive image is an evaluation from a tourist. Tourists' emotional impression directly affects satisfaction level. If the experience is more than expected, satisfaction will be high. However, if the experience is less than expected, satisfaction will not be high. Tourists have indicated Semarang has tourism-related products and services that need to be maintained by the Government: accessibility, diverse cuisine, city cleanliness (public spaces), and friendliness of residents. If the city's tourism offerings are already well maintained, it will make tourist come again in the future. The concept of urban tourism is still relatively new in Indonesia. Some cities have developed the concept of urban tourism, such as Bandung, Jakarta, and Surabaya, so the authors suggestion further research as the model and results in this study can be used as consideration to confirm the concept of urban tourism.

\section{REFERENCES}

Artuger, S., Cetinsoz, B.C., \& Kilic, I. (2013). The effect of destination image on déstination loyalty: an application in Alanya. European Journal of Business and Management, 5, (13), 124-136.

Beerli, A., \& Martin, J. (2004). Factors influencing destination image. Annals of Tourism Research, 31(3), $657-681$.

Chiu, W., Zeng S., \& Cheng P. (2016). The influence of destination image and tourist satisfaction on tourist loyalty: a case study of Chinese tourists in Korea. International Journal of Culture, Tourism and Hospitality Research, 10(2), 223-234.

Coban, S. (2012). The effects of the image of destination on tourist satisfaction and loyalty: The case of Cappadocia. European Journal of Social Sciences, (2) 222-232.

Griffin, T., \& Dimanche, F. (2017). Urban tourism: the growing role of VFR and immigration. Journal of Tourism Future. 3(2), 103-113.

Hanifa, A. (2012). Mengubah kesan kota transit Semarang jadi kota wisata. http://www.republika.co.id/ berita/nasional/jawa-tengah-diy-nasional/12/04/20/m2rnm3-mengubah-kesan-kota-transit-semarangjadi-kota-wisata.

Kotler, P., \& Keller, K.L. (2009). Marketing management (13th ed.). New Jersey: Pearson Education Inc.

Oliver R. (1999). Whence consumer loyalty? Journal of Marketing, 63(4), 33-44.

Page, S.J., \& Hall, C. M. (2003). Managing urban tourism. London: Pearson Education.

Prayag, G. (2011). Antecedents of tourist loyalty to Mauritius: the role and influence of destination image, place attachment, personal involvement, and satisfaction. Journal of Travel Research, 20(10), 1-15.

Selby, M. (2004). Understanding urban tourism: image, culture and experience. I.B. Tauris \& Co. Ltd: New York.

Wang, T. L., Tran, P. T. K., \& Tran, V. T. (2017). Destination perceived quality, tourist satisfaction and word-of-mouth. Tourism Review, 72(4), 392-410.

Wardhani, A. D. (2012). Evolusi aktual aktivitas urban tourism di kota Bandung dan dampaknya terhadap pembentukan tempat-tempat rekreasi. Jurnal Pembangunan Wilayah dan Kota. 8(4). 371-382.

Yeh, S., Chen, C., \& Liu Y., 2012. Nostalgic emotion, experiential value, destination image, and place attachment of cultural tourists. In Advances in Hospitality and Leisure, 8, 167-187.

Yuksel, A., Yuksel, F., \& Billim, Y. (2010). Destination attachment: effects on customer satisfaction and cognitive, affective and conative loyalty. Tourism Management, 31(2), 274-284. 